\title{
Predatory Pricing: A Rejoinder
}

\author{
By Phillip Areeda ${ }^{\dagger}$ and Donald F. Turner $\ddagger$
}

A further point-by-point reply to Professor Williamson would unduly tax the readers of the Journal. The principal differences between us are adequately set forth in the several articles, ${ }^{1}$ and we leave the dispute where it sits. It does seem worthwhile, however, to comment on two points.

The first concerns Williamson's general characterization of our approach. Although we appreciate his kind words about our original contribution, we do not understand the repeated criticisms that we ignore a would-be predator's strategic motivations and that we rest solely on static economic analysis. Such characterizations do not fairly express our views about the formulation of wise and administrable legal rules.

Our original article ${ }^{2}$ expressly addressed pricing arising out of a monopolist's desire to exclude entry. We discussed at considerable length the problem of pricing that excludes potentially efficient rivals without giving the public the benefits of long-run competitive pricing. The long-run welfare implications of such pricing concerned us in the original article and still do. The question we posed there and continue to ask is whether such considerations can be incorporated into sensible legal rules that would do more good than harm.

Williamson agrees that forcing a monopolist to maintain preexisting prices would be undesirable. His proposal ${ }^{3}$ to limit expansion of the monopolist's output is an intriguing and more plausible approach. But it suffers from the difficulties analyzed in our last article, ${ }^{4}$ which also

$\dagger$ Professor of Law, Harvard University.

$\mp$ Bussey Professor of Law, Harvard University.

1. Areeda \& Turner, Predatory Pricing and Related Practices under Section 2 of the Sherman Act, 88 Harv. L. Rev. 697 (1975); Williamson, Predatory Pricing: A Strategic and Welfare Analysis, 87 Yale L.J. 284 (1977); Areeda \& Turner, Williamson on Predatory Pricing, 87 YALE L.J. 1337 (1978); Williamson, A Preliminary Response, 87 Yale L.J. 1353 (1978); Williamson, Williamson on Predatory Pricing II, 88 YALE L.J. 1183 (1979).

2. Areeda \& Turner, Predatory Pricing and Related Practices under Section 2 of the Sherman Act, 88 HARv. L. REv. 697 (1975).

3. See Williamson, Predatory Pricing: A Strategic and Welfare Analysis, 87 YALE L.J. 284, 295-99, 331-37 (1977).

4. See Areeda \&- Turner, Williamson on Predatory Pricing, 87 Yale L.J. 1337, 1340-50 (1978) (output-restriction rule deficient on grounds of administrability and welfare properties). 
pointed out that Williamson himself is often forced to rely on cost-based rules in defining predatory pricing. In saying this, we do not pretendnor have our previous writings suggested-that a marginal-cost test (using a surrogate of average variable cost where appropriate) is free from administrative difficulties or other imperfections. Simply put, our position is this: giving due recognition to those problems and to the various long-run and "strategic" considerations urged by Williamson and others, theoretical uncertainties and administrative considerations suggest that the marginal-cost test is nonetheless the most sensible solution. Such a conclusion, of course, does not rest on eternal verities. We would be happy to endorse a better solution should one appear.

Second, Williamson makes much of the fact that neither in our original article nor in our response to his first article do we address the issue of "fairness," which in his view "is among the values that antitrust law is designed to foster." 5 We have not dwelt on "fairness" because it is far too unruly a concept to serve any useful purpose in formulating appropriate antitrust rules. Depending on how it is conceived, it may or may not be consistent with competition. Fairness is indeed a value served by antitrust, but only in the sense that fairness is a by-product of a pro-competitive, efficiency-oriented policy. For example, competition promotes "fairness" by ensuring that prices are equal to costs. Fairness in this sense may support conclusions reached on competitive, efficiency, and administrative grounds, and invoking it for that purpose may do no harm. But beyond that, it can only mislead, as in the myriad ways in which plaintiffs seek to invoke "fairness" to protect themselves, not competition or consumers. If Williamson is right on economic and administrative grounds, his invocation of "fairness" is superfluous. If he is wrong, his appeal to "fairness" can only deflect antitrust law from an appropriate test for predatory pricing.

5. Williamson, Williamson on Predatory Pricing II, 88 YALE L.J. 1183, 1197 (1979). 


\section{The Yale Law Journal}

Volume 88, Number 8, July 1979

\begin{tabular}{cc}
\multicolumn{2}{c}{ Alice Armitage Colburn } \\
Editor-in-Ghief \\
Boris Feldman & Peter A. Barnes \\
Note \& Topics Editor & Managing Editor \\
& \\
James A. Geraghty & Mark S. Campisano \\
Scott M. Matheson & Morgan J. Frankel \\
Roberta Romano & Robert A. Katzmann \\
Kenneth T. Roth & James C. Snipes \\
Note Editors & Article \& Book Review \\
& Editors
\end{tabular}

William B. Beekman

Richard H. Fallon

Russell V. Randle

Craig B. Brod

Gregory P. Goeckner

Anne C. Ryan

David M. Crowe

Isabelle R. Gunning

Debra A. Valentine

R. Laird Hart

Secretaries to the Editors M. Olive Butterfield, Pamela Willmott

\section{Student Contributors to This Issue}

Boris Feldman, Mental Disability and the Right to Vote

R. Laird Hart, Legal Ethics and the Destruction of Evidence

Scott M. Matheson, Indian Reserved Water Rights: The Winters of Our Discontent

Russell V. Randle, Forcing Technology: The Clean Air Act Experience

Kenneth T. Roth, In Defense of Fault in Defamation Law 